\title{
Pengaruh Karakteristik Individu dan Kompensasi terhadap Turnover Intention
}

\author{
Ratih Prameswari Wulan Asih* \\ Prodi Manajemen, Fakultas Ekonomi dan Bisnis, Universitas Islam Bandung, \\ Indonesia. \\ *rwulanasih23@gmail.com
}

\begin{abstract}
This study aims to determine the Individual Characteristics and Compensation for Turnover Intention at the Perisai Husada Main Clinic. This research is categorized as descriptive and verification research as a quantitative approach with an instrument in the form of a questionnaire. The sampling technique in this study used saturated samples because all 55 employees of the Perisai Husada Main Clinic were made into the population. Data collection using questionnaires and interviews. Test the validity of the instrument using Pearson's product moment while the reliability test with the Alpha cronbanch with the help of SPSS 25. 0 Measuring instruments prove to be valid and reliable for research instruments. Hypothesis testing of this study uses multiple linear regression analysis. The results of the study prove that: (1) Individual characteristics significantly positive effect on Turnover Intention with a value of $\beta=0.394$ and sig $=0,000$, the contribution of individual characteristics to Turnover Intention $0.434=43.4 \%$; (2) Compensation has a positive effect on Turnover Intention with a value of $\beta=0.530$ and sig 0,000 , contribution of Compensation to Turnover Intention $0.569=56.9 \%$; (3) Individual Characteristics and Compensation have a significant positive effect on Turnover Intention with a result of $\mathrm{R}^{2}=0.622$. This means that Individual Characteristics and Compensation is $62.2 \%$ while the remaining $27.8 \%$ is influenced by other variables outside the variables studied.
\end{abstract}

Keywords: Compensation, Individual Characteristic, Turnover Intention.

Abstrak. Penelitian ini bertujuan untuk mengetahui Karakteristik Individu dan Kompensasi terhadap Turnover Intention pada Klinik Utama Perisai Husada. Penelitian ini di kategorikan sebagai penelitian deskriptif dan verikatif sebagai pendekatan kuantitatif dengan instrument berupa kuesioner. Teknik pengambilan sampel dalam penelitian ini menggunakan sampel jenuh karena seluruh karyawan Klinik Utama Perisai Husada sebanyak 55 orang dijadikan populasi. Pengumpulan data menggunakan kuesioner dan wawancara. Uji validitas instrumen dengan menggunakan product moment pearson sedangkan uji reliabilitas dengan cronbanch Alpha dengan bantuan SPSS 25. 0 Alat ukur terbukti valid dan reliabel untuk instrument penelitian. Uji hipotesis penelitian ini menggunakan analisis regresi linear berganda. Hasil penelitian membuktikan bahwa: (1) Karakteristik Individu berpengaruh positif signifikan terhadap Turnover Intention dengan nilai $\beta=0,394$ dan sig $=0,000$, kontribusi karakteristik individu terhadap Turnover Intention $0,434=$ 43,4\%; (2) Kompensasi berpengaruh positif terhadap Turnover Intention dengan nilai $\beta=0,530$ dan sig 0,000, kontribusi Kompensasi terhadap Turnover Intention 0,569 $=56,9 \%$; (3) Karakteristik Individu dan Kompensasi berpengaruh positif signifikan terhadap Turnover Intention dengan hasil $\mathrm{R}^{2}=0,622$. Hal ini berarti Karakteristik Individu dan Kompensasi $62,2 \%$ sedangkan sisanya 27,8\% dipengaruhi oleh variabel lain di luar variabel yang diteliti.

Kata Kunci: Karakteristik Individu, Kompensasi, Turnover Intention. 


\section{A. Pendahuluan}

Perkembangan dunia perekonomian saat ini sangatlah pesat, hal ini berjalan seiring pesatnya pula perkembangan zaman yang semakin menuntut manusia untuk terus mengikuti perkembangannya sebagai salah satu hal yang tidak dapat dipisahkan dalam kehidupan manusia sehari-hari. Hal ini dialami pula oleh perusahaan-perusahaan yang saat ini tengah berkembang untuk memenuhi kebutuhan sumber daya manusia yang dimilikinya dan juga untuk W1keberlangsungan perusahaan. Maka dari itu perusahaan harus mengikuti perkembangan zaman yang pesat seperti saat ini.

Perusahaan dalam melaksanakan kegiatannya, pasti akan selalu berusaha untuk meningkatkan kinerja setiap individu dari organisasi-organisasi yang ada di perusahaan agar mendapatkan karyawan yang sesuai kualifikasi agar tujuan perusahaan bisa tercapai. Untuk menemukan karyawan yang tepat di posisi jabatan yang tepat, perusahaan melakukan beberapa kegiatan seperti merekrut, menyeleksi, melatih, dan mempertahankan karyawan yang berkualitas juga memiliki kinerja yang optimal. Perusahaan perlu memperhatikan karyawan, agar setiap karyawan dapat berkontribusi dengan baik terhadap perusahaan. Karyawan yang tidak mendapat perhatian dari perusahaan dan kebutuhannya tidak terpuaskan biasanya akan memilih untuk meninggalkan pekerjaan mereka (turnover intention) dan akan menjadi hambatan perusahaan untuk mencapai tujuannya. (T Rahmalia, 2017)

Menurut penelitian Anindya Prawitasari (2016) turnover intention merupakan suatu keinginan karyawan untuk mengundurkan diri dari perusahaan secara sukarela yang disebabkan beberapa faktor, seperti adanya kesempatan pekerjaan yang lebih menarik di perusahaan lain. Sedangkan menurut Sutanto \& Kurniawan (2016) turnover intention merupakan niat pergantian karyawan yang ditandai dengan berbagai hal menyangkut perilaku karyawan, antara lain: keberanian untuk melanggar ketertiban di perusahaan, keberanian untuk menentang dan memprotes atasan maupun rekan kerja, juga cara menyelesaikan semua tanggung jawab yang sangat berbeda dari biasanya.

Jika menurut penelitian Alvia Santoni dan Muhammad Nusjirwan Harahap (2018) turnover intention dalam dunia bisnis merupakan hal yang wajar, tetapi hal tersebut bisa menjadi indikasi masalah bagi perusahaan jika terjadi turnover karyawan yang tinggi dan akan timbul penurunan kinerja karyawan. Penurunan kinerja karyawan memberikan dampak negatif dalam pencapaian tujuan perusahaan, maka oleh sebab itu manajemen harus mempelajari sikap dan perilaku para karyawan dalam perusahaan tersebut.

Dengan demikian, turnover intention dapat berakibat kerugian bagi perusahaan, terutama dengan hilangnya sumber daya manusia yang dimiliki serta kemungkinan bocornya informasi atau rahasia perusahaan pada kompetitor (Puangyoykeaw dan Nishide, 2015). Lebih lanjut, dengan tingkat turnover karyawan yang tinggi, perusahaan menjadi tidak efektif karena hilangnya karyawan yang berpengalaman (Zakaria dan Astuty, 2017). Turnover karyawan yang tinggi juga akan mengganggu jalannya operasional perusahaan dan pada akhirnya akan berpengaruh pada target (goal) yang ingin dicapai perusahaan (Khaidir \& Sugiati, 2016). Oleh karena itu, perusahaan perlu mengkontrol tingkat turnover intention yang terjadi dan selanjutnya menetapkan kebijakan agar tingkat turnover yang terjadi bisa diminimalisir. Agar dapat mengkontrol turnover intention pada karyawannya, perusahaan terlebih dahulu harus mengetahui faktor-faktor apa saja yang memicu atau menentukan tingkat tinggi dan rendahnya turnover pada karyawan. Menghindari terjadinya turnover pada karyawan tidak mudah, karena turnover intention timbul apabila terjadi variabelvariabel yang mempengaruhinya seperti karakteristik individu dan kompensasi yang harus diakomodasikan dengan baik dan diterima oleh semua karyawan di dalam suatu perusahaan.

Dalam suatu organisasi di sebuah perusahaan, setiap karyawan memiliki perbedaan individu dengan individu lainnya, karakteristik individu merupakan suatu hal yang nyata. Hal ini dikarenakan setiap karyawan yang ada dalam perusahaan memiliki karakter yang berbeda- 
beda. Orang yang memiliki perbedaan kepribadian, tentu berbeda pula cara berinteraksi mereka dengan atasan, rekan kerja maupun bawahan. Karena karakteristik individu ini dapat menjadi tolak ukur seseorang ketika melakukan pekerjaan dan ketika seseorang mengambil suatu keputusan. Tipe karakter seseorang yang berfikir panjang dan memikirkan dampak negatif maupun risiko, tentu akan menghasilkan keputusan terbaik pula bagi dirinya sendiri maupun bagi perusahaan.

Penelitian mengenai karakteristik individu menurut Toni Munandar (2017) dan Stephen P. Robbins, Mary Coulter (2016) menyatakan bahwa faktor-faktor yang mudah di definisikan dan tersedia dalam berkas personalia seorang pegawai menampilkan beberapa karakteristik individu yang melekat ada pada diri individu, diantaranya ialah: usia, jenis kelamin, status perkawinan, jumlah tanggungan, masa kerja, kepribadian, persepsi, dan sikap.

Menurut penelitian H. Peoni (2014) karakteristik individu yang heterogen pada setiap individu dapat menciptakan kontribusi kinerja yang berbeda pada perusahaan. Pegawai yang memiliki karakteristik baik akan menjadikan pegawai tersebut lebih mudah dalam mengerjakan pekerjaannya, sehingga kinerja yang dihasilkan menjadi optimal dan berpengaruh sangat baik bagi perusahaan. Begitupula sebaliknya, pegawai dengan karakteristik yang buruk akan menghambat perusahaan dalam beroperasi dan berkembang dengan menimbulkan sikap-sikap yang negatif. Berdasarkan hal tersebut dapat dipastikan bahwa perusahaan memiliki kriteria tertentu mengenai pegawai yang akan mereka pekerjakan yang sesuai dengan kebutuhan perusahaan.

Selain karakteristik individu dalam organisasi, karyawan tidak lepas dari kepuasan kompensasi, karena kompensasi merupakan sesuatu yang wajib diterima oleh karyawan sebagai imbalan jasa mereka terhadap perusahaan, dan tentu menjadi faktor utama yang akan mendorong seseorang melaksanakan suatu kegiatan guna mendapat kinerja yang terbaik. Organisasi selaku induk kerja harus memberikan dan memuaskan kompensasi yang layak, adil dan merata yang mampu mendorong para karyawan untuk bekerja dengan produktif, baik dalam kompensasi finansial maupun kompensasi non finansial. Namun minoritas pada perusahaan swasta, diskriminasi sudah menjadi hal yang lumrah, hal ini terjadi dikarenakan banyaknya faktor-faktor pertimbangan pemberian gaji pokok pada karyawan, misalnya penetapan atas ijazah terakhir, sifat pekerjaan, pendidikan informal, bahkan hubungan dengan orang dalam yang terdahulu atau hubungan keluarga yang ikut serta menentukan besarnya gaji pokok seseorang. Karena hal ini pula, tidak sedikit karyawan yang ingin mencari pekerjaan lebih baik karena merasa tidak puasnya besaran kompensasi yang diterima.

Penelitian yang dilakukan Fransiskus Billy Sandy (2019) menyatakan bahwa kompensasi mempengaruhi tinggi dan rendahnya turnover intention. Kemudian penelitian yang dilakukan oleh Ghafoor (2017) beberapa studi empiris telah menemukan bahwa ketidakpuasan pada kompensasi adalah faktor yang mendominasi niat pergantian karyawan. Namun kompensasi menurut penelitian Gebremedhin Weldeyohannes (2015) organisasi harus mengakui kompensasi sebagai motivator utama karyawan, sebagai alat penting dan biaya untuk organisasi. Semua bentuk pengembalian itu karyawan dapatkan sebagai bagian dari hubungan kerja yang disebut kompensasi. Pemberian sebuah kompensasi terhadap karyawan pasti memiliki tujuan positif.

Menurut penelitian Agrisna Puspita Sari (2018) kompensasi merupakan masalah yang sulit dan membingungkan, tidak hanya karena pemberian kompensasi merupakan salah satu tugas yang paling kompleks, tetapi juga salah satu aspek yang paling berarti bagi karyawan maupun perusahaan. Sebab karena adanya kompensasi, seseorang mau menjadi karyawan di perusahaan tertentu. Besarnya kompensasi mencerminkan ukuran nilai karyawan diantara karyawan lainnya, dan pemberian kompensasi secara adil dan merata, besar pengaruhnya terhadap semangat kerja para karyawan. Sebab tingkat kompensasi absolut (mutlak) untuk karyawan menentukan skala kehidupannya, sedangkan kompensasi relatif itu untuk menjadikan karyawan agar memiliki tolak ukur kepastian dalam hidupnya, seperti menunjukkan status, martabat dan harga diri mereka sebagai individu yang berbeda-beda persepsinya, kebutuhannya, kepentingan, dan hal yang lainnya sebagai kepuasan tersendiri dalam kehidupannya. 
Penelitian mengenai kompensasi menurut Gebremedhin Weldeyohannes (2015) menyatakan bahwa kompensasi itu terdiri dari (1) kompensasi non finansial dengan indikator kepuasan atas imbalan karir, imbalan sosial, jaminan sosial, asuransi, tunjangan siklus hidup; (2) kompensasi finansial dengan indikator upah, gaji dan insentif;

Perusahaan atau objek yang saya ambil untuk penelitian adalah Klinik Utama Perisai Husada, yang merupakan jenis usaha dalam menyelenggarakan pelayanan medik spesialistik. Spesialistik berarti mengkhususkan pelayanan pada satu bidang tertentu berdasarkan disiplin ilmu, golongan umur, organ atau jenis penyakit tertentu. Klinik ini dipimpin seorang dokter spesialis. Berdasarkan beberapa perijinannya, klinik ini hanya dapat dimiliki oleh badan usaha berupa PT, ataupun CV. Klinik Utama Perisai Husada dapat sukses, tidak terlepas dari manajemen perusahaannya sebagai penunjang terhadap fungsi utama yaitu pelayanan kesehatan yang terdiri dari manajemen sumber daya manusia.

Sumber daya manusia pada Klinik Utama Perisai Husada berfungsi sebagai salah satu yang melayani kesehatan, yang menyelenggarakan dan menyediakan pelayanan medis dasar atau spesialistik, diselenggarakan oleh lebih dari satu jenis tenaga kesehatan dan dipimpin oleh seorang tenaga medis (direktur utama). Dalam pelaksanaan layanan tersebut, Klinik Utama Perisai Husada selalu berusaha menjaga kualitas pelayanan untuk memuaskan para pasien, salah satu upaya yang dilakukan maka Klinik Utama Perisai Husada telah dibekali dengan standar kinerja yang jelas dan dilakukan pelaksanaan penilaian kinerja secara periodik yang dilakukan oleh sebuah tim dengan tujuan agar kualitas sumber daya manusia tetap terjaga dan bisa lebih menampilkan kinerja yang produktif dengan tingkat turnover karyawan yang rendah.

Berdasarkan hasil wawancara yang penulis lakukan dengan karyawan sumber daya manusia Klinik Utama Perisai Husada, penulis mendapatkan informasi mengenai masalah yang dihadapi oleh Klinik Utama Perisai Husada berkaitan dengan karakteristik individu dan kompensasi, antara lain tidak seimbangnya program untuk pasien dan karyawan, padahal perusahaan pelayanan kesehatan tetapi hanya diaplikasikan untuk konsumennya, tidak pada karyawannya. Sehingga karyawan tidak sedikit yang mudah sakit karena menumpuknya pekerjaan namun tidak direalisasikannya program olahraga untuk karyawan sampai akhirnya karyawan tidak merasa adanya kesejahteraan dari segi kesehatan, lalu tingginya tingkat turnover karena faktor latar belakang maupun karakteristik individu para pimpinan yang heterogen juga masa kerja pimpinan yang lebih lama atau lebih berpengalaman sehingga membuat bawahan merasa tidak nyaman bekerja dengan perilaku pimpinannya, serta kurangnya kepuasan kompensasi yang diberikan perusahaan dengan yang diterima karyawan walau tidak sebagian besar karyawan merasakan hal yang sama. Oleh karena itu untuk menjalin hubungan agar setiap individu saling terbuka, jujur, adil, antara pimpinan dan karyawan dengan pencapaian program yang baik maka akan mendorong dan membuat karyawan untuk bekerja dengan senang hati sehingga turnover pun dapat dihindari. Baik buruknya karakteristik individu dan kompensasi yang diaplikasikan, akan berpengaruuh terhadap tinggi rendahnya tingkat turnover pada karyawan Klinik Utama Perisai Husada.

Berdasarkan permasalahan-permasalahan yang ada di Klinik Utama Perisai Husada dapat disimpulkan bahwa faktor karakteristik individu dan kompensasi yang menjadi penyebab munculnya beberapa permasalahan yang saat ini terjadi di Klinik Utama Perisai Husada tersebut terutama tingkat turnover yang tinggi. Berdasarkan data-data yang penulis peroleh, maka penulis akan menjadikan data-data tersebut sebagai bahan penelitian yang akan penulis lakukan di Klinik Utama Perisai Husada.

Berikut data dalam bentuk tabel:

Tabel 1. Data Turnover Karyawan Klinik Utama Perisai Husada Tahun 2017 s/d 2019 


\begin{tabular}{|c|c|c|c|c|c|}
\hline Tahun & $\begin{array}{c}\text { Jumlah } \\
\text { Karyawan } \\
\text { Awal } \\
\text { Tahun }\end{array}$ & $\begin{array}{c}\text { Jumlah } \\
\text { Karyawan } \\
\text { yang } \\
\text { Keluar }\end{array}$ & $\begin{array}{c}\text { Jumlah } \\
\text { Karyawan } \\
\text { Masuk }\end{array}$ & $\begin{array}{c}\text { Jumlah } \\
\text { Karyawan } \\
\text { Akhir } \\
\text { Tahun }\end{array}$ & $\begin{array}{c}\text { Turnover } \\
\text { Rate }\end{array}$ \\
\hline 2017 & 55 & 8 & 1 & 48 & $0,135 \%$ \\
\hline 2018 & 48 & 3 & 2 & 47 & $0,021 \%$ \\
\hline 2019 & 47 & 3 & 11 & 55 & $-0,155 \%$ \\
\hline
\end{tabular}

Sumber: Manajer SDM Klinik Utama Perisai Husada

Dari data turnover yang didapat pada Tabel 1.1 dapat dihitung persentase tingkat turnover karyawan pada Klinik Utama Perisai Husada dengan menggunakan rumusan LTO (Labour Turnover) pertahun. Rumusan perhitungan untuk mengetahui besarnya turnover yakni sebagai berikut:

$$
\begin{aligned}
& \qquad \begin{array}{c}
\text { Turnover }=\frac{(\text { karyawan } \text { keluar }- \text { karyawan diterima })}{1 / 2(\text { karyawan awal }+ \text { karyawan akhir })} \times 100 \% \\
\text { Sumber: Malayu Hasibuan }(2009)
\end{array} \\
& \text { Turnover tahun } 2017=\frac{8-1}{\frac{1}{2}(55+48)} \times 100 \%=0,135 \% \\
& \text { Turnover tahun } 2018=\frac{3-2}{\frac{1}{2}(48+47)} \times 100 \% \quad=0,021 \% \text { Turnover tahun } 2019 \\
& =\frac{3-11}{\frac{1}{2}(47+55)} \times 100 \%=-0,155 \%
\end{aligned}
$$

Berdasarkan perhitungan LTO (Labour Turnover) pertahun, persentase tingkat turnover karyawan Klinik Utama Perisai Husada terus mengalami penurunan dari tahun 2017 sampai dengan tahun 2019. Karyawan yang paling banyak keluar ada pada tahun 2017, 8 dari karyawan yang keluar adalah 2 karyawan tetap yang sudah memiliki masa kerja selama kurang lebih 10 tahun, dan 6 karyawan yang masih kontrak. Berdasarkan hasil wawancara dengan pihak SDM diperoleh beberapa alasan karyawan keluar dari perusahaan, yaitu karyawan diterima kerja di perusahaan yang lain, tidak adanya kesejahteraan hingga munculnya rasa jenuh dan karir yang dirasakan tidak berkembang dengan kompensasi yang diberikan. Dan faktor utama yaitu adanya keluh kesah dari karyawan mengenai hubungan karyawan dengan pemimpin yang kurang mendukung dalam melaksanakan pekerjaan. Kondisi-kondisi diatas menarik minat peneliti untuk melakukan penelitian dengan judul : Pengaruh Karakteristik Individu dan Kompensasi terhadap Turnover Intention (Studi Kasus pada Karyawan Klinik Utama Perisai Husada Bandung)

Berdasarkan latar belakang masalah yang dirumuskan tersebut, maka penulis merumuskan masalah penelitian yang akan dilakukan yaitu:

1. Untuk mengetahui karakteristik individu karyawan pada Klinik Utama Perisai Husada

2. Untuk mengetahui kompensasi pada Klinik Utama Perisai Husada

3. Untuk mengetahui turnover intention pada Klinik Utama Perisai Husada

4. Untuk mengetahui seberapa besar pengaruh karakteristik individu karyawan terhadap turnover intention pada Klinik Utama Perisai Husada

5. Untuk mengetahui seberapa besar pengaruh kompensasi terhadap turnover intention pada Klinik Utama Perisai Husada

6. Untuk mengetahui seberapa besar pengaruh karakteristik individu karyawan dan kompensasi terhadap turnover intention pada Klinik Utama Perisai Husada

\section{B. Landasan Teori}




\section{Karakteristik Individu}

Definisi karakteristik adalah fitur pembeda dari seseorang atau sesuatu. Karakteristik didefinisikan sebagai kualitas atau sifat. Karakteristik adalah sesuatu atau ciri yang khas dari seseorang atau sesuatu. Dalam ilmu biologi karakteristik seringkali dikaitkan dengan anatomi dan ciri khas dan hewan lainnya.

Karakteristik manusia dalam geografi adalah fitur dan corak fasilitas di permukaan bumi yang dibuat oleh manusia. Ini termasuk bangunan, bendungan, jalan dll. Karakteristik manusia dalam biologi adalah watak dan sifat-sifat manusia yang mendasar. Ini termasuk ciriciri fisik, tindakan manusia dsb.

Setiap manusia mempunyai karakteristik individu yang berbeda-beda antara yang satu dengan yang lainnya. Dalam Kamus Besar Bahasa Indonesia (KBBI) yang dimaksud dengan karakteristik adalah ciri atau sifat yang berkemampuan untuk memperbaiki kualitas hidup. Sedangkan individu adalah perorangan; oleh seorang.

Menurut penelitian Normariati Silaban (2018) karakter individu yang heterogen menimbulkan bentuk interaksi kinerja individu dalam organisasi. Setiap individu dalam organisasi, semuanya akan berperilaku berbeda satu sama lain dan perilakunya adalah ditentukan oleh masing-masing lingkungannya yang memang berbeda. Individu membawa ke dalam tatanan organisasi suatu karakter kemampuan, kepercayaan pribadi, pengharapan kebutuhan dan pengalaman masa lalunya. Karakteristik yang dipunyai individu ini akan dibawanya manakala memasuki lingkungan baru yaitu organisasi atau yang lainnya. Organisasi juga merupakan suatu lingkungan yang mempunyai karakteristik seperti keteraturan yang diwujudkan dalam susunan hirarki, pekerjaan, tugas wewenang, tanggungjawab, sistem penggajian, sistem pengendalian dan sebagainya.

Menurut R Andi Sularso (2016) secara singkat karakteristik individu adalah ciri khusus seseorang. Manusia mempunyai karakteristik individu yang berbeda-beda antara yang satu dengan yang lainnya. Masa depan seorang individu dalam organisasi tidak bergantung pada kinerja saja. Manajer juga menggunakan ukuran subyektif yang bersifat pertimbangan dengan apa yang dipersepsikan oleh penilai sebagai karakter atau perilaku karyawan yang baik atau buruk akan mempengaruhi penilaian, dalam hal tersebut sesuai dengan Dewi Prihatini (2016) bahwa karakteristik individu merupakan proses psikologi yang mempengaruhi individu dalam memperoleh, mengkonsumsi, menerima barang dan jasa serta pengalaman.

Menurut Peoni (2014) yang berkaitan dengan karakteristik individu, bahwa individu membawa pengaruh terhadap tatanan organisasi, kemampuan, kepercayaan diri, pengharapan kebutuhan dan pengalaman. Karakteristik yang dimiliki individu akan memasuki suatu lingkungan baru, yakni organisasi. Menurut Toni Munandar (2017) dan Stephen P. Robbins, Mary Coulter (2016) menjelaskan karakteristik lain yang melekat pada individu terdiri dari ciri-ciri biografis, kepribadian, persepsi dan sikap.

Dan kesimpulan beberapa definisi diatas, dapat dikatakan bahwa segala sesuatu yang terjadi tergantung bagaimana individu itu dapat menerima persepsinya dari setiap orang yang ada di lingkungannya yang bersifat heterogen, dan karakter individu tidak bisa dapat diubah selain keinginan untuk mengevaluasi dirinya sendiri. Karena karakteristik individu itu sudah hakikat setiap umat manusia dari lahir ke dunia.

\section{Kompensasi}

Menurut Normarianti Silaban (2018) pemberian kompensasi karyawan oleh perusahaan memiliki tujuan tertentu. Diantaranya adalah untuk menghargai prestasi karyawan, menjamin keadilan gaji karyawan, mempertahankan karyawan atau mengurangi turnover karyawan, memperoleh karyawan yang bermutu, pengendalian biaya, dan memenuhi peraturan-peraturan. Kompensasi memiliki fungsi yang cukup penting dalam memperlancar jalannya roda perusahaan.

Kompensasi adalah segala sesuatu yang diterima oleh karyawan sebagai layanan ketenagakerjaan. Kompensasi diterima oleh karyawan sebagai pengganti kontribusi layanan mereka kepada perusahaan (Saluy et al., 2018). Kompensasi adalah salah satu fungsi utama pengelolaan sumber daya manusia yang berhubungan dengan 
semua jenis dari penghargaan kepada individu sebagai pertukaran dalam melaksanakan tugas organisasi. Menurut Tantri Yanuar Rahmat Syah (2018), kompensasi adalah ketentuan layanan dengan imbalan yang layak dan adil bagi karyawan karena mereka telah berkontribusi pada pencapaian organisasi. Sementara menurut (Riansari et al., 2014), prinsip imbalannya bisa dibagi menjadi dua, yaitu imbalan untuk pengembalian intrinsik dan ekstrinsik. Berdasarkan teori beberapa uraian di atas, secara konseptual kompensasi dapat didefinisikan sebagai semua bentuk pengembalian intrinsik untuk karyawan yang diterima sebagai imbalan dari layanan organisasi.

Dan kesimpulan dari semua definisi diatas, dapat dikatakan bahwa kompensasi finansial dan kompensasi non finansial sudah menjadi kewajiban setiap perusahan memberikan secara adil dan merata pada setiap karyawan yang bekerja sebagai hak karyawan setelah memberikan kinerja terbaiknya pada perusahaan guna mencapai tujuan.

\section{Turnover Intention}

Salah satu bentuk perilaku karyawan yaitu keinginan berpindah (turnover intention) yang berujung pada keputusan untuk meninggalkan pekerjaannya. Tingginya tingkat turnover dapat diprediksi dari seberapa besar keinginan berpindah yang dimiliki anggota suatu organisasi atau perusahaan. Turnover intention atau keinginan berpindah dapat diartikan sebagai keinginan individu untuk meninggalkan organisasi dan mencari alternatif pekerjaan lain. Saat ini tingginya tingkat turnover intention telah menjadi masalah serius bagi banyak perusahaan. Proses identifikasi terhadap faktor-faktor yang mempengaruhi niat untuk pindah (turnover intention) menjadi suatu hal yang penting untuk dipertimbangkan dan menjadi sesuatu yang efektif untuk menurunkan angka turnover yang sebenarnya.

Keluarnya pegawai dari suatu organisasi atau seringkali dikenal dengan istilah turnover dapat disebabkan oleh banyak alasan, baik dari sisi organisasi maupun keinginan pegawai. Keluarnya pegawai dengan inisiatif yang berasal dari organisasi biasanya dikenal dengan istilah Pemutusan Hubungan Kerja (PHK). Sedangkan inisiatif yang merupakan keinginan pegawai disebut pengunduran diri secara sukarela. Perilaku keluar dari organisasi yang dimaksudkan dalam penelitian ini adalah pengunduran diri yang berasal dari inisiatif pegawai yaitu secara sukarela.

Abelson (2015:105) menyatakan bahwa sebagian besar karyawan yang meninggalkan perusahaan karena alasan sukarela dapat dikategorikan atas perpindahan kerja sukarela yang dapat dihindarkan (avoidable voluntary turnover) dan perpindahan kerja sukarela yang tidak dapat dihindarkan (unavoidable voluntary turnover). Avoidable voluntary turnover dapat disebabkan karena alasan berupa gaji, kondisi kerja, atasan atau ada perusahaan lain yang dirasakan lebih baik, sedangkan unavoidable voluntary turnover dapat disebabkan karena perubahan jalur karir atau faktor keluarga.

Menurut Harnoto (2017:94) turnover intention adalah kadar atau intensitas dari keinginan untuk keluar dari perusahaan. Intensi keluar di definisikan sebagai intensi seseorang untuk melakukan pemisahan aktual (turnover) dari satu organisasi (Good et al, dalam Sunjoyo \& Harsono 2013:204). Sementara Indriantoro (dalam Indriantoro \& Suwandi, 2014:103) menyatakan intensi turnover mengacu pada hasil evaluasi individu mengenai kelanjutan hubungannya dengan organisasi dan belum diwujudkan dalam tindakan pasti meninggalkan organisasi.

Mobley, dkk (2015:204) mendefinisikan intensi keluar sebagai keinginan pemberhentian keterikatan dalam suatu organisasi oleh individu yang menerima kompensasi dari organisasi tersebut. Menurut Arnold and Feldman (2015:109) intention to quit adalah keinginan berpindah dari karyawan yang mengacu pada kelanjutan hubungannya dengan perusahaan dan belum diwujudkan dalam tindakan pasti meninggalkan perusahaan tersebut.

Mobley et, all (2015) menerangkan bahwa proses turnover dimulai sejalan dengan meningkatnya ketidakpuasan dari karyawan tersebut terhadap pekerjaannya, sehingga pilihan untuk berhenti dari pekerjaan juga meningkat. Model tersebut menunjukkan bahwa tahapan kognitif dimulai pada saat individu mulai berpikir untuk berhenti dari pekerjaannya. Hal ini 
melibatkan penilaian antara hal-hal yang diharapkan dari pekerjaannya yang baru dengan harga yang harus dibayar jika meninggalkan pekerjaannya sekarang.

Selanjutnya apabila individu menemukan bahwa terdapat peluang untuk mendapatkan alternative pekerjaan lain yang lebih memuaskan, maka pencarian untuk pekerjaan baru akan dimulai (intention to search). Hal ini melibatkan penilaian karyawan terhadap pendapat atau tidaknya diterimanya hasi pekerjaan tersebut. Jika sesuatu atau beberapa alternatif pekerjaan lain telah ditemukan, maka alternatif-alternatif tersebut akan dibandingkan dengan pekerjaan saat ini. Selanjutnya, apabila alternatif pekerjaan telah ditemukan, tahapan kognitif karyawan akan berlanjut pada tahap ketiga yaitu intensi karyawan tersebut untuk meninggalkan pekerjaan (intention to quit).

Dengan beberapa definisi diatas, dapat disimpulkan bahwa intensi karyawan untuk meninggalkan pekerjaannya adalah kelanjutan dari dua tahapan kognitif yang mendahuluinya yaitu berpikir untuk berhenti dari pekerjaannya dan intensi untuk mencari pekerjaan lain. Ketika individu memiliki intensi untuk meninggalkan pekerjaannya, maka individu tersebut akan mengambil kesimpulan untuk tetap bertahan atau untuk meninggalkan pekerjaannya. Selanjutnya, apabila keputusan yang diambil individu adalah meninggalkan pekerjaannya, maka terjadilah apa yang dikatakan turnover sukarela yang sebenarnya.

\section{Hasil Penelitian dan Pembahasan}

Besar Pengaruh Karakteristik Individu terhadap Turnover Intention Klinik Utama Perisai Husada

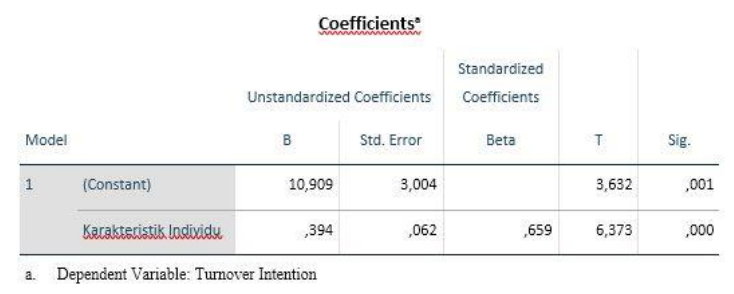

Tabel di atas menunjukkan nilai thitung yang didapat adalah sebesar 6,373 dan nilai ttabel adalah sebesar 2,006 yang berarti nilai thitung $>$ ttabel atau $6,373>2,006$ dan nilai signifikan $0,000<0,05$. Artinya Ho ditolak dan Ha diterima itu berarti terdapat pengaruh signifikan antara karakteristik individu terhadap turnover intention karyawan di Klinik Utama Perisai Husada dengan arah hubungan yang positif.

Hipotesis pertama dalam penelitian ini berbunyi "karakteristik individu berpengaruh signifikan terhadap turnover intention karyawan di Klinik Utama Perisai Husada". Berdasarkan analisis regresi diketahui bahwa pada variabel karakteristik individu diperoleh nilai koefisien beta $(\beta)$ sebesar 0,394 dan $\rho=0,000$; hal ini menunjukkan bahwa karakteristik individu berpengaruh terhadap turnover intention karyawan di Klinik Utama Perisai Husada. Kontribusi pengaruh karakteristik individu terhadap turnover intention karyawan di Klinik Utama Perisai Husada sebesar 43,4\%, maka dapat disimpulkan bahwa hipotesis pertama diterima.

\section{Besar Pengaruh Kompensasi terhadap Turnover Intention Klinik Utama Perisai Husada}

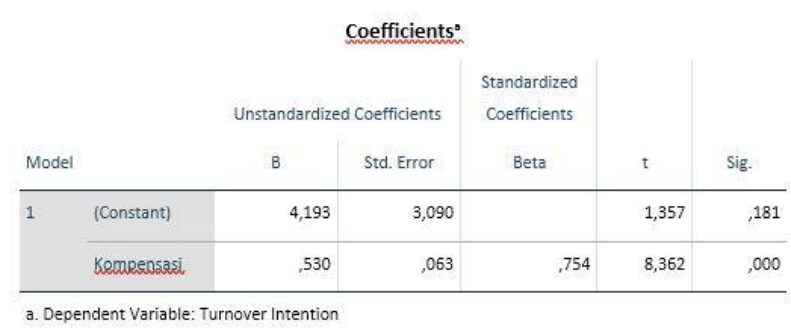


Tabel di atas menunjukkan nilai thitung yang didapat adalah sebesar 11,394 dan nilai ttabel adalah sebesar 2,006 yang berarti nilai thitung > ttabel atau 8,362>2,006 dan nilai signifikan $0,000<0,05$. Artinya Ho ditolak dan Ha diterima itu berarti terdapat pengaruh signifikan antara kompensasi terhadap turnover intention karyawan di Klinik Utama Perisai Husada dengan arah hubungan yang positif.

Hipotesis kedua dalam penelitian ini berbunyi "kompensasi berpengaruh terhadap turnover intention karyawan di Klinik Utama Perisai Husada". Berdasarkan analisis regresi diketahui bahwa pada variabel kompensasi diperoleh nilai koefisien beta $(\beta)$ sebesar 0,530 dan $\rho=0,000$; hal ini menunjukkan bahwa kompensasi berpengaruh terhadap turnover intention karyawan di Klinik Utama Perisai Husada. Kontribusi pengaruh kompensasi terhadap turnover intention karyawan di Klinik Utama Perisai Husada sebesar 56,9\%, maka dapat disimpulkan bahwa hipotesis pertama diterima. Hasil penelitian menunjukkan bahwa kompensasi berpengaruh terhadap turnover intention karyawan di Klinik Utama Perisai Husada. Artinya kompensasi yang tinggi (adil \& merata) maka tingkat turnover intention karyawan pun akan rendah.

\section{Besar Pengaruh Karakteristik Individu dan Kompensasi terhadap Turnover Intention Klinik Utama Perisai Husada}

\begin{tabular}{|c|c|c|c|c|c|c|}
\hline \multicolumn{7}{|c|}{ ANOVA: } \\
\hline Model & & Sum of Squares & df & Mean Square & $\mathrm{F}$ & Sig. \\
\hline \multirow[t]{3}{*}{1} & Regression & 1865,086 & 2 & 932,543 & 42,811 &, $000^{\circ}$ \\
\hline & Residual & 1132,712 & 52 & 21,783 & & \\
\hline & Total & 2997,798 & 54 & & & \\
\hline
\end{tabular}

Hasil perhitungan pada tabel anova, menunjukkan nilai Fhitung dengan df $1=2$ dan df $2=52$ adalah 42,811, dengan signifikansi $=0,000$. Pengujian dengan membandingkan signifikansi $=0,000$ dengan $\alpha=5 \%(0,05)$ maka $0,000<0,05$ artinya Ho ditolak dan Ha diterima. Apabila pengujian dengan membandingkan Fhitung $=42,811>$ Ftabel $=3,175$ maka Ho ditolak dan Ha diterima. Oleh karena itu dapat disimpulkan bahwa terdapat pengaruh yang signifikan dari karakteristik individu dan kompensasi secara bersama-sama (simultan) terhadap turnover intention karyawan di Klinik Utama Perisai Husada.

\section{Kesimpulan}

Dari hasil penelitian mengenai "Pengaruh Karakteristik Individu dan Kompensasi terhadap Turnover Intention pada Klinik Utama Perisai Husada Bandung”, maka penulis dapat menarik kesimpulan sebagai berikut:

1. Dari hasi pengujian deskriptif didapatkan bahwa karakteristik individu karyawan pada Klinik Utama Perisai Husada terasuk dalam kategori baik.

2. Dari hasi pengujian deskriptif didapatkan bahwa kompensasi pada Klinik Utama Perisai Husada terasuk dalam kategori baik.

3. Dari hasi pengujian deskriptif didapatkan bahwa turnover intention pada Klinik Utama Perisai Husada terasuk dalam kategori rendah.

4. Dari hasil pengujian parsial dapat disimpulkan bahwa pengaruh variabel karakteristik individu terhadap turnover intention berpengaruh signifikan dengan persentase pengaruh sebesar $43,4 \%$.

5. Dari hasil pengujian parsial dapat disimpulkan bahwa pengaruh variabel kompensasi terhadap turnover intention berpengaruh signifikan dengan persentase pengaruh sebesar $56,9 \%$.

6. Dari hasil pengujian simultan yang dilakukan penulis membuktikan adanya pengaruh yang signifikan dari karakteristik individu karyawan dan kompensasi berpengaruh terhadap turnover intention pada Klinik Utama Perisai Husada dengan persentase pengaruh sebesar $62,2 \%$ 


\section{E. Saran}

Berdasarkan hasil penelitian yang dilakukan, maka penulis mengajukan saran kepada Klinik Utama Perisai Husada sebagai bahan pertimbangan perusahaan yaitu sebagai berikut :

1. Meskipun secara keseluruhan karakteristik individu dalam kategori cukup, perlu ditingkatkan tentang minat karyawan dalam bekerja, karena jika dilihat dari data yang telah diberikan oleh pihak HRD. Untuk beberapa aspek masih ada yang harus diperbaiki. Sebaiknya, diperlukan evaluasi saat melakukan rekrutmen dengan melakukan reference check yang bertujuan untuk memastikan apakah data yang diberikan oleh karyawan valid/tidak, dan menghindari kepalsuan.

2. Kompensasi secara keseluruhan dirasa puas oleh seluruh karyawan, namun tetap Klinik Utama Perisai Husada harus mengikuti kompensasi yang diatur peraturan pemerintah atas gaji yang diberikan harus sesuai UMR. Dan sebaiknya, pihak manajemen melakukan program family gathering sebagai kompensasi non finansial, dimana program tersebut bertujuan untuk membangun team kerja yang lebih kompak, mempererat hubungan persaudaraan antar karyawan dan atasan juga bahawan, hingga membangun kembali semangat dalam bekerja.

3. Untuk turnover intention, karyawan sebaiknya saling menguatkan satu sama lain, memberi dukungan kepada atasan, rekan kerja maupun bawahan secara kekeluargaan. Karyawan memberi saran untuk pengembangan karir di perusahaan agar perusahaan merealisasikan programnya, karena jika bersyukur atas apa yang dimiliki, tentu tidak akan ada niat karyawan untuk mencari pekerjaan yang lebih baik di tempat lain. Juga dukungan internal akan mempengaruhi tingkat motivasi untuk bekerja dan nyaman untuk melaksanakan pekerjaan. Dengan begitu, tentu tingkat turnover intention pada Klinik Utama Perisai Husada pun akan rendah.

\section{Daftar Pustaka}

[1] Bhakta, M., \& Nagy, M. S. (2005). Are higher pay increases necessarily better. Applied HRM Research, 10(1), 1-12.

[2] Bosomtwe, T. E., \& Obeng, B. (2018). The Link between Organizational Culture and Turnover Intention among Employees in Ghana. International Journal of Contemporary Research and Review, 9(08), 20951-20958.

[3] Candra, D. M., Hana, S. W. L., \& Wulandari, D. (2018). Compensation And Turnover Intention In Coal Mining Support Companies In South Kalimantan. International Journal of Scientific \& Technology Research, 7(4), 202-205.

[4] Chen, J., De Cesari, A., Hill, P., \& Ozkan, N. (2018). Initial compensation contracts for new executives and financial distress risk: An empirical investigation of UK firms. Journal of Corporate Finance, 48, 292-313.

[5] Chepchumba, T., \& Kimutai, B. (2017). The relationship between employee compensation and employee turnover in small businesses among Safaricom dealers in Eldoret municipality, Kenya. International Journal of Economics, Commerce and Management, 5(2), 490-501.

[6] Eklund, M. A. (2019). Compensation for Financial Performance. In Fairness of CEO Compensation (pp. 39-65). Springer, Cham.

[7] Eklund, M. A. (2019). Compensation for Non-financial Performance (ESG Scores). In Fairness of CEO Compensation (pp. 67-74). Springer, Cham.

[8] Eklund, M. A. (2019). Compensation for Non-financial Performance (ESG Scores). In Fairness of CEO Compensation (pp. 67-74). Springer, Cham.

[9] Farrington, D. P. (2017). Mediating the Effects of Poverty, Gender, Individual Characteristics, and External Constraints on Antisocial Behavior: A Test of the Social Development Model and Implications for Developmental Life-Course Theory. In Integrated Developmental and Life-course Theories of Offending (pp. 103-134). 
Routledge.

[10] Hamali, A. Y. (2016). Pemahaman Manajemen Sumber Daya Manusia: Strategi Mengelola Karyawan.

[11] Haque, A., Fernando, M., \& Caputi, P. (2019). The relationship between responsible leadership and organisational commitment and the mediating effect of employee turnover intentions: an empirical study with Australian employees. Journal of Business Ethics, 156(3), 759-774.

[12] Hur, H., \& Hawley, J. (2019). Turnover behavior among US government employees. International Review of Administrative Sciences, 0020852318823913.

[13] Ibrahim, S. H. (2019). Effect of Non-Financial Compensation on Performance of Employees of Shaba Water Company in Borama District, Somaliland. AUAJ, 1(001), 119-124.

[14] Istiyani, A., Wulan, H. S., \& Diana, P. (2018). The Effect Of Compensation, Work Stress And Career Development On Turnover Intention With Work Leadership As An Intervening Variable (Case Study At PT. Rajawali Nusindo 2013-2017 Period). Journal of Management, 4(4). 